\title{
Population Structure and Pathotype Diversity of the Wheat Blast Pathogen Magnaporthe oryzae 25 Years After Its Emergence in Brazil
}

\author{
João L. Nunes Maciel, Paulo C. Ceresini, Vanina L. Castroagudin, \\ Marcelo Zala, Gerrit H. J. Kema, and Bruce A. McDonald
}

First author: Embrapa Trigo, Rod. BR 285, km 294, 99001-970, Passo Fundo, RS, Brazil; second and third authors: Universidade Estadual Paulista (UNESP), Departamento de Fitossanidade, Engenharia Rural e Solos, 15385-000, Ilha Solteira, São Paulo, Brazil; fourth and sixth authors: Swiss Federal Institute of Technology (ETH Zurich), Institute of Integrative Biology (IBZ), Universitaetstrasse 2, LFW B16, 8092 Zurich; fifth author: University and Research Centre, Plant Research International, 6700AA, Wageningen UR, The Netherlands.

First and second authors contributed equally to this manuscript.

Accepted for publication 19 July 2013.

\begin{abstract}
Maciel, J. L. N., Ceresini, P. C., Castroagudin, V. L., Zala, M., Kema, G. H. J., and McDonald, B. A. 2014. Population structure and pathotype diversity of the wheat blast pathogen Magnaporthe oryzae 25 years after its emergence in Brazil. Phytopathology 104:95-107.

Since its first report in Brazil in 1985, wheat blast, caused by Magnaporthe oryzae (anamorph: Pyricularia oryzae), has become increasingly important in South America, where the disease is still spreading. We used 11 microsatellite loci to elucidate the population structure of the wheat blast pathogen in wheat fields in central-western, southeastern, and southern Brazil. No subdivision was found among the wheat-infecting

scale. Although the clonal fraction was relatively high and the two mating type idiomorphs (MAT1-1 and MAT1-2) were not at similar frequencies, the clone-corrected populations from Distrito Federal and Goiás, Minas Triangle, and São Paulo were in gametic equilibrium. Based on these findings, we propose that populations of the wheat blast pathogen exhibit a mixed reproductive system in which sexual reproduction is followed by the local dispersal of clones. Seedling virulence assays with local wheat cultivars differentiated 14 pathotypes in the current population. Detached head virulence assays differentiated eight virulence groups on the same wheat cultivars. There was no correlation between seedling and head reactions.
\end{abstract} populations, consistent with high levels of gene flow across a large spatial
The blast disease caused by the Ascomycetous fungus Magnaporthe oryzae (anamorph Pyricularia oryzae) is the most important fungal disease on rice $(33,35)$. The emergence of the blast pathogen on wheat is relatively recent, dating back to 1985 (23), when the first epidemic was detected in Paraná State, southern Brazil. Wheat blast recently emerged as a serious disease in Paraguay and Bolivia (16). There are no reports of $M$. oryzae infecting wheat outside of South America. M. oryzae also infects barley, rye, and triticale in areas of central-western and southern Brazil (3).

Since its emergence in 1985, wheat blast has become increasingly important in Brazil. The pathogen has become widely distributed across most of the wheat-producing areas in Brazil over the last 25 years because of a lack of resistant cultivars and effective fungicides (4). Despite a continuous breeding effort over the past decades (15), the majority of available wheat cultivars are very susceptible to blast, though 'BR 18 Terena', 'BRS 229', and 'MGS 3 Brilhante' are considered tolerant under field conditions $(15,27)$. However, the tolerance of these varieties has been erratic in different regions of Brazil $(47,49)$. Wheat blast is currently considered the main obstacle to the expansion of wheat cropping in the Brazilian Cerrado areas $(16,21)$.

The biology and ecology of $M$. oryzae have been investigated intensively. The pathogen can be dispersed efficiently over short

Corresponding author: P. C. Ceresini;

E-mail address: paulo.ceresini@ bio.feis.unesp.br

* The $\boldsymbol{e}$-Xtra logo stands for "electronic extra" and indicates that the online version contains two supplemental tables. Figures 1, 2, and 3 appear in color online.

http://dx.doi.org/10.1094/PHYTO-11-12-0294-R

(C) 2014 The American Phytopathological Society and long distances via airborne inoculum (51) and infected seed (19). M. oryzae is a heterothallic Ascomycete requiring two mating types to produce sexual fruiting structures (perithecia, asci, and ascospores) (52). Under lab conditions, the wheat-infecting strains cross easily (50). However, the relative importance of sexual ascospores and asexual conidia in epidemics of wheat blast remains unknown.

A wide range of host plants within the family Poaceae can provide a reservoir of primary inoculum for the wheat-infecting $M$. oryzae. Strains of M. oryzae isolated from wheat were able to infect Poaceous plants from six tribes and also produced mature perithecia when crossed with strains from Eleusine coracana (Chlorideae), Brachiaria plantaginea (Paniceae), and Setaria indica (Paniceae) (50). Despite the presence of rice blast in Brazil since 1912 (5), rice is considered a nonhost for M. oryzae isolated from wheat. The wheat- and rice-derived populations of $M$. oryzae were described as genetically distinct and host specific based on distinct DNA-fingerprinting profiles, the absence of crosspathogenicity between wheat- and rice-derived strains, and sexual incompatibility between the two host-specialized populations (9).

Few studies have investigated genetic diversity in the wheatinfecting blast pathogen in Brazil. The few studies published to date indicated the occurrence of genetic and pathotype variability $(47,49)$ but there is no information regarding population genetic structure and the extent of genetic differentiation among geographical populations of wheat-infecting $M$. oryzae in Brazil. Basic knowledge regarding current levels of pathotypic variation and the geographical distribution of pathotypes is lacking.

Our two major goals in this study were to (i) elucidate the population genetic structure of the wheat blast pathogen in Brazil and (ii) determine the levels of pathotypic diversity and the geographical distribution of $M$. oryzae pathotypes in Brazil. 
Under the first goal, we addressed the following questions. Are geographically distinct pathogen populations genetically differentiated? How is gene diversity distributed within and among regional populations of $M$. oryzae 25 years after the first epidemics? What are the relative contributions of sexual and asexual reproduction to population genetic structure? To answer these questions, we used 11 simple-sequence repeat (SSR) loci (25) to compare $M$. oryzae populations sampled from wheat fields in central-western, southeastern, and southern Brazil. Four riceinfecting populations of $M$. oryzae from Brazil were included as sympatric host-specialized populations of the pathogen. Historical and contemporary patterns of gene flow among populations were determined using classical and coalescent-based historical migration analyses. We also measured genotypic diversity and the distribution of mating type idiomorphs and tested for departures from gametic equilibrium. We combined the outcomes of these analyses to evaluate the evolutionary potential of M. oryzae in the Brazilian wheat agroecosystem. Under the second goal we addressed several questions. Do local wheat cultivars show a differential response to different $M$. oryzae genotypes? Do different geographical populations differ in pathotype variation? Are any pathotypes widely disseminated? We addressed these questions using a set of wheat cultivars described by Cruz et al. (15) and compared their reaction to blast at seedling and heading stages of development. We also examined the occurrence and distribution of two known avirulence genes, AVR-PITA and AVRI-CO39.

\section{MATERIALS AND METHODS}

Fungal populations. Four regional populations of $M$. oryzae were sampled from naturally infected wheat fields in centralwestern (Distrito Federal and Goiás), southeastern (Minas Triangle from Minas Gerais and São Paulo), and southern Brazil (Paraná) during 2005 to 2008 (Table 1). This region includes $\approx 58 \%$ of the total wheat cropping area in Brazil (10). Each of these regional populations was composed of several field collections sampled along transects of 150 to $250 \mathrm{~km}$ in each region. In all, 8 to 30 isolates were recovered from each field (16 on average) from three to seven fields in each region. Diseased wheat heads from plants with blast symptoms were collected at random within each field. Samples were dried at room temperature for 2 to 4 days inside paper envelopes; then, single-spore isolations were made as described earlier (50) and transferred to oatmeal agar (oatmeal, 72 g/liter). For long-term storage, cultures were grown for 10 to 14 days at $27^{\circ} \mathrm{C}$ with autoclaved filter paper disks, which were then stored at $-20^{\circ} \mathrm{C}(45)$. Three rice-infecting collections of $M$. oryzae originating from different sources and sampled from different regions in Brazil were included for comparison. DNA extraction from lyophilized tissue was done as described earlier $(6,34)$ using the Wizard magnetic DNA purification system for food (Promega Corp., Madison, WI). In total, 148 wheat-infecting and 36 rice-infecting isolates were included in the analyses (Table 1).

Microsatellite genotyping and fragment analyses. Eleven microsatellite (SSR) loci were used to genotype the isolates using fluorescent-labeled primers $(1,25)$. Polymerase chain reaction (PCR) amplifications were performed in 96-well plates in a total volume of $20 \mu \mathrm{l}$ with $5 \mu \mathrm{l}$ of genomic DNA (5 to $15 \mathrm{ng}$ final concentration), $2 \mu \mathrm{l}$ of $10 \times$ reaction buffer $(100 \mathrm{mM} \mathrm{KCl}, 100$ $\mathrm{mM}\left[\mathrm{NH}_{4}\right]_{2} \mathrm{SO}_{4}, 200 \mathrm{mM}$ Tris- $\mathrm{HCl}, 20 \mathrm{mM} \mathrm{MgCl}_{2}$, and $0.1 \%$ Triton X-100, pH 8.8) (New England Biolabs, Hitchin, UK), 0.3 $\mu \mathrm{M}$ each labeled (Applied Biosystems, Foster City, CA) and nonlabeled primer (Microsynth, Balgach, Switzerland), $0.1 \mathrm{mM}$ each dNTP, and 0.5 U of Taq Polymerase (New England Biolabs). All amplification reactions were carried out in a Biometra Tgradient thermocycler. The fluorescent-labeled PCR products, along with a fluorescently labeled size standard (GeneScan-500 LIZ; Applied Biosystems), were electrophoresed using an ABI PRISM 3100 (Applied Biosystems) automated sequencer. Five and six loci were run together in two distinct sets (set 1: 47-48, 63-64, 319-320, 505-506, and 607-608; set 2: 77-78, 87-88, 233-234, 409-410, 533-534, and 657-658). Allele fragment analyses were performed with the GeneMapper program, version 4, supplied by Applied Biosystems. Two control isolates (WBRZ_732 and WBRZ_755) were included in every run of 94 samples.

Data analyses. Genotype diversity. A multilocus microsatellite genotype (MLMG) was determined for each strain using the program GENODIVE (version 2.0b7; Institute for Biodiversity and Ecosystem Dynamics, Universiteit van Amsterdam, Amsterdam) (31). Isolates with the same MLMG were treated as clones (Supplemental Table 1). Four indices of clonal diversity were measured, including (i) the number of genotypes per population, (ii) genotypes shared among populations, (iii) the clonal fraction (the proportion of isolates originating from asexual reproduction) (56), and (iv) Stoddart and Taylor's genotypic diversity $G_{o}(43)$. To test whether pairs of populations differed in their genotypic diversity, we used a bootstrapping approach (resampling with replacement) (28) using 10,000 permutations with subsampling to

TABLE 1. Brazilian wheat- and rice-infecting populations of the blast pathogen Magnaporthe oryzae used in this study

\begin{tabular}{|c|c|c|c|c|}
\hline Host, region, population ${ }^{2}$ & Location (states) & Counties & $\begin{array}{l}\text { Sampling } \\
\text { years }\end{array}$ & $N$ \\
\hline \multicolumn{5}{|l|}{ Wheat-infecting isolates } \\
\hline \multicolumn{5}{|l|}{ Central-Western Brazil } \\
\hline \multicolumn{5}{|l|}{ Southeastern Brazil } \\
\hline${ }^{1}$ MG06, MG07, and MG08 & Minas Triangle (Minas Gerais) & $\begin{array}{l}\text { Coromandel; Indianópolis, Perdizes and Unaí; } \\
\text { Buritis and Uberaba }\end{array}$ & $2006-2008$ & 31 \\
\hline${ }^{2} \mathrm{SP} 05$ & São Paulo & Panarapanema & 2005 & 13 \\
\hline \multicolumn{5}{|l|}{ Southern Brazil } \\
\hline Total, wheat & $\cdots$ & $\cdots$ & $\cdots$ & 148 \\
\hline \multicolumn{5}{|l|}{ Rice-infecting isolates } \\
\hline${ }^{3} \mathrm{RC} 0708$ & Goiás and Tocantins & $\begin{array}{l}\text { São Miguel do Araguaia (GO), Dueré, } \\
\text { Formoso, Lagoa da Confusão (TO) }\end{array}$ & $2007-2008$ & 12 \\
\hline${ }^{4} \mathrm{RC} 96$ & Rio Grande do Sul & Several counties & 1996-2001 & 13 \\
\hline${ }^{5} \mathrm{RC} 93$ & $\begin{array}{l}\text { Mato Grosso, Rio Grande do Sul and Santa } \\
\text { Catarina }\end{array}$ & Unknown & $1993-2003$ & 11 \\
\hline
\end{tabular}


match the size of the smallest population and scaled by the maximum number of expected genotypes (22).

Population differentiation. These analyses were performed on the clone-corrected data set in which only one individual of each MLMG was included per population. The distribution of gene diversity and the degree of population subdivision was assessed using hierarchical analysis of molecular variance (18). As the distance measure, we used the sum of squared size differences $\left(R_{S T}\right)$ between two haplotypes (41). Significance of the fixation indexes was tested using 1,023 permutations by a nonparametric approach (18) using the program ARLEQUIN, version 3.11 (17).

Demographic parameters and historical migration. The effective population sizes and the asymmetrical historical migration rates between the wheat- and rice-infecting populations of $M$. oryzae were estimated using a maximum likelihood test based on the Markov Chain Monte Carlo method implemented in MIGRATE, version 3.2.1 (7). Because none of the wheatinfecting populations were subdivided (an assumption of the model), we could not infer historical migration among them. The data type chosen was microsatellite data with Brownian motion and assuming a stepwise mutation model. Initial estimates of gene flow among populations were obtained with MIGRATE, using two replicates of 10 initial chains and two long final chains and a static heating scheme with four temperatures (1.0, 1.3, 2.6, and 3.9). Initial chains were performed with 2,500 samples and a sampling interval of 20 (50,000 steps), with 2,500 trees recorded per short sample. The final two chains were carried out with 25,000 samples, a sampling interval of 20 (500,000 steps), and a burn-in of 10,000 discard trees and 25,000 trees recorded per long chain. The confidence interval for $\theta$ and migration parameter $M$ was calculated using a percentile approach (6). A likelihood ratio test (LRT) was used to test the hypothesis of symmetric $M$. The LRT implemented in MIGRATE compares the maximum likelihood of the migration estimates with the likelihood when $M$ is restricted to the same value as the mean of the estimates from a population pair. If $P \leq 0.05$ for a particular LRT, we would reject the null hypothesis that the test values (i.e., symmetrical migration values) are equal to the full model estimates under which the genealogies were sampled.

Frequencies of mating type idiomorphs among haplotypes of the wheat-infecting population. We determined the presence or absence of the mating type idiomorphs MAT1-1 and MAT1-2 $(11,44,53)$ using a PCR assay. For MAT1-1, we used the primers A1 (5'-AGCCTCATCAACGGCAA-3') and A5 (5'-GGCACG AACATGCGATG- $\left.3^{\prime}\right)$; for $M A T 1-2$, we used the primers B15 (5'CTCAATCTCCGTAGTAG-3') and B16 (5'-ACAGCAGTATAGC CTAC- $3^{\prime}$ ). Primer sequences were provided by Didier Tharreau, INRA, Montpellier, France. The rice-infecting isolates ARG-245-1 and URU-6-2 were included as positive controls for MAT1-1 and the isolates $90-\mathrm{IN}-2-1$ and $\mathrm{TH}-21033$ as positive controls for MAT1-2. Each test was repeated once.
Test for gametic equilibrium. We used MULTILOCUS version 1.3 (2) to measure the index of association $\left(I_{A}\right)(29)$ and test the hypothesis of panmixia. These tests were implemented using 1,000 randomizations and fixing missing data during randomizations. Under panmixia, $I_{A}$ values are expected to not differ significantly from zero.

Virulence spectrum of $M$. oryzae on wheat seedlings and detached heads. $M$. oryzae isolates were recovered from longterm storage, transferred to petri dishes containing oatmeal agar, and incubated at $25^{\circ} \mathrm{C}$ under fluorescent light with a 16-h photoperiod for 12 to 14 days (45). Mycelium was scraped from the agar surface with a sterile spatula. Sterile distilled water (2 to $3 \mathrm{ml}$ ) was added to the plates to wash the surface of the colonies. The water was removed and the plates were left under the same conditions for 3 days. This scraping and washing procedure typically increases the production of spores (27). The plates were washed with a solution of Tween 80 (two drops per liter) to release spores. The spore concentration applied to both wheat seedlings and detached heads was adjusted to $1 \times 10^{5} \mathrm{conidia} / \mathrm{ml}$ using a Neubauer counting chamber.

The virulence of 69 wheat-infecting isolates was measured on seven wheat cultivars ('Anahuac 75', 'BR 24', 'MGS 3 Brilhante', 'BR 18 Terena', 'BRS 220', 'BRS Buriti', and 'BRS 229'), on rice ('Maratelli'), and barley ('Pleasant'). These $69 \mathrm{M}$. oryzae isolates represented 38 MLMGs detected in the population. In all, 10 to 12 seeds of each cultivar were sown in $300-\mathrm{ml}$ plastic pots containing fertilized field soil. Plants were grown for 12 to 14 days in greenhouses at $26^{\circ} \mathrm{C}$ and $80 \%$ relative humidity and thinned to eight plants per pot prior to inoculation. Inoculated plants had three to four true leaves and were at growth stage 14 (54). An observational unit, representing one repetition, was a single pot with eight plants. Two pots with eight plants each (i.e., two repetitions) were assessed for each cultivar and the pots were randomly distributed in 18-pot trays. Plant inoculations were conducted as described by Bonnan et al. (8). The spore suspension $(15 \mathrm{ml})$ was applied to each 18-pot tray in an inoculation chamber using a spraying system that delivered a uniform distribution of inoculum onto the leaf surfaces. Following inoculation, the trays were placed into transparent plastic bags, sealed, and incubated as described above. The plastic bags were removed after $24 \mathrm{~h}$. Evaluation of disease severity on wheat seedlings was made 6 to 7 days after inoculation by measuring, on detached leaves, the percentage of wheat leaf area affected by blast using the image analysis software ImageJ (37). When a cultivar had, on average, $<10 \%$ diseased leaf area, it was considered resistant (R) to wheat blast at the seedling stage. Digital image analysis allowed us to precisely measure the degree of quantitative (partial) resistance on seedlings. The entire experiment was replicated twice. Because no treatment-experimental replicate interactions were observed (Table 2), the data from the two experiments were combined, resulting in four repetitions of each experimental unit.

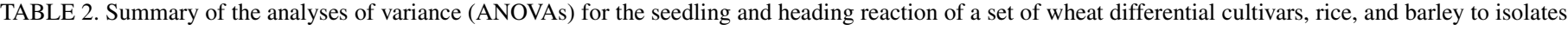
of the blast pathogen Magnaporthe oryzae ${ }^{\mathrm{z}}$

\begin{tabular}{|c|c|c|c|c|c|c|c|c|}
\hline \multirow[b]{2}{*}{ Sources of variation } & \multicolumn{4}{|c|}{ Seedling reaction: percentage of infected leaf area } & \multicolumn{4}{|c|}{ Head reaction: percentage of infected head area } \\
\hline & df & $F$ & $P$ value & Significance & df & $F$ & $P$ value & Significance \\
\hline Experiments & 1 & 0.04 & 0.847 & NS & 1 & 0.43 & 0.510 & NS \\
\hline Isolates within experiments & 68 & 10.51 & $<0.001$ & $* * *$ & 26 & 16.32 & $<0.001$ & $* * *$ \\
\hline Varieties within experiments & 8 & 212.66 & $<0.001$ & $* * *$ & 7 & 25.56 & $<0.001$ & $* * *$ \\
\hline Interaction (experiments $\times$ isolates) & 68 & 1.03 & 0.413 & NS & 26 & 0.22 & 1.000 & NS \\
\hline Interaction (experiments $\times$ varieties) & 8 & 0.14 & 0.997 & NS & 7 & 0.14 & 0.995 & NS \\
\hline \multicolumn{9}{|l|}{ Combined ANOVA (Exp. $1+$ Exp. 2) } \\
\hline Isolates & 68 & 36.12 & $<0.001$ & $* * *$ & 26 & 30.96 & $<0.001$ & $* * *$ \\
\hline Varieties & 8 & 548.86 & $<0.001$ & $* * *$ & 7 & 58.51 & $<0.001$ & $* * *$ \\
\hline Interaction (isolates $\times$ varieties) & 544 & 3.76 & $<0.001$ & $* * *$ & 182 & 2.70 & $<0.001$ & $* * *$ \\
\hline Treatments & 620 & 14.35 & $<0.001$ & $* * *$ & 215 & 7.93 & $<0.001$ & $* * *$ \\
\hline Total & 2,483 & $\ldots$ & $\ldots$ & $\ldots$ & 863 & $\ldots$ & $\ldots$ & $\ldots$ \\
\hline
\end{tabular}

${ }^{\mathrm{z}} \mathrm{NS}=$ nonsignificant. $* * *=$ significant at $P \leq 0.001$. 
To determine the reaction of wheat cultivars at the heading stage, $27 \mathrm{M}$. oryzae isolates representing 17 MLMGs were inoculated onto detached heads of the same seven cultivars. The heads originated from plants grown to maturity outside the greenhouse in large pots under natural conditions. In addition to the seven wheat cultivars used for the seedling assay, we included 'CNT-8' for the wheat head assay. The heads were collected between flowering and early grain filling, corresponding to plant growth stages 60 to 70 (54). Four heads of each wheat cultivar were fixed in 4-by-4-by-20-cm blocks of hydrophilic polyurethane foam that were saturated with water and wrapped in plastic film. An observational unit, representing one repetition, was a single polyurethane foam block with four wheat heads. Sixteen blocks (two for each cultivar) were randomly distributed in two plastic boxes and covered with transparent lids. Inoculum $(15 \mathrm{ml})$ was applied to each box using the same inoculation system described earlier. After inoculation, the boxes were covered with transparent lids, sealed to maintain $100 \%$ humidity, and incubated as described for the seedling assays. Evaluation of disease severity on wheat heads was made 6 to 7 days after inoculation by assessing the percentage of each wheat head affected by blast using the digital image analysis software ImageJ (37). Variation in wheat head blast severity is observed in Figure 1. A wheat cultivar that showed, on average, $<10 \%$ diseased head area was considered $\mathrm{R}$ at the heading stage. We also assessed the level of quantitative (partial) resistance to blast on wheat heads. The entire experiment was replicated twice. Because no treatment-experimental replication interactions were observed (Table 2), the data from the two experiments were combined, resulting in four repetitions of each experimental unit.

Analyses of variance (ANOVAs) were performed using the SAS statistics software package (version 9.1 of the SAS System for Windows; SAS Institute Inc., Cary, NC), using PROC MIXED to evaluate the fixed effects (treatments) of interest for each experiment, which involved host cultivars, pathogen isolates, and their interaction. To determine whether the two experimental replications could be combined, we also checked for treatmentexperimental replication interactions. For pairwise comparisons between means of cultivars, we applied the Scott and Knott test at $P \leq 0.05(39,40)$. The Scott and Knott test is a powerful clustering method favored over other pairwise multiple comparison tests due to the absence of ambiguity among groups and type I error rates in accordance with the nominal levels (38).

Presence or absence of avirulence genes AVR-PITA and AVR1-CO39. The presence or absence of two avirulence genes,
AVR-PITA and AVR1-CO39, was assessed using a PCR test. PCR primers were the same used by Couch et al. (12). Amplifications using Pita-F (5'-CGCCTTTTATTGGTTTAATTCG-3') and Pita$\mathrm{R}$ (5'-CCTCCATTCCAACACTAACG-3') were performed with an annealing temperature of $60^{\circ} \mathrm{C}$. Amplifications using primers Co39F-327 (5'-TGCGATATAATGGCCAAACA-3') and Co39R800 (5'-GACCGATCTGTCGGGAAGTA-3') were performed with an annealing temperature of $55^{\circ} \mathrm{C}$. Two independent PCR amplifications were performed for each gene. Lack of amplification was interpreted as evidence for a loss of function due to deletion or rearrangement of the gene. The rice-infecting isolates 90-IN-2-1 and TH-21033 were included as positive controls for $A V R-P I T A$ and negative controls for AVRI-CO39. The wheatinfecting isolate WBRZ_732 was included as a positive control for AVR1-CO39 and a negative control for AVR-PITA. Every PCR reaction included the microsatellite marker pyrms607-608 as a positive control for amplification.

\section{RESULTS}

Genotypic diversity. Clonal fractions were 15 to $78 \%$, with an overall fraction of $68 \%$. The genotypic diversity varied from 4.7 in Distrito Federal and Goiás to 16.1 in Paraná (Table 3). In total, 48 distinct MLMGs were identified. Thirteen of these MLMGs were shared among populations. There were no MLMGs shared between wheat- and rice-infecting populations of $M$. oryzae.

Hierarchical distribution of gene diversity and differentiation among and within host populations. The highest population differentiation was observed between the wheat-infecting and rice-infecting groups (between group component $\Phi_{C T} \approx 0.89$, $P \leq 0.001$ ) (Table 4). In contrast, pairwise within-group comparisons among wheat-infecting populations indicated that they were not subdivided (Table 5) (pairwise $\Phi_{S T}=0.027, P=0.59$ ). There also was no differentiation among the rice-infecting populations (Table 5) (pairwise $\Phi_{S T}=0.065, P=0.41$ ). The pairwise $\Phi_{S T}$ values of subdivision between populations within the wheat-infecting group (Table 5) were significantly lower than observed for the wheatversus rice-infecting comparisons ( $t$ value $=60.99 ; P \leq 0.001$ ).

Demographic parameters and historical migration. There was no difference in population size between the wheat- and the rice-infecting populations (Table 6). Estimates of directional gene flow were consistent with low and symmetrical historical migration between the Brazilian wheat- and rice-infecting populations of $M$. oryzae ( 0.2 to 0.7 migrants/generation) (Table 6 ).

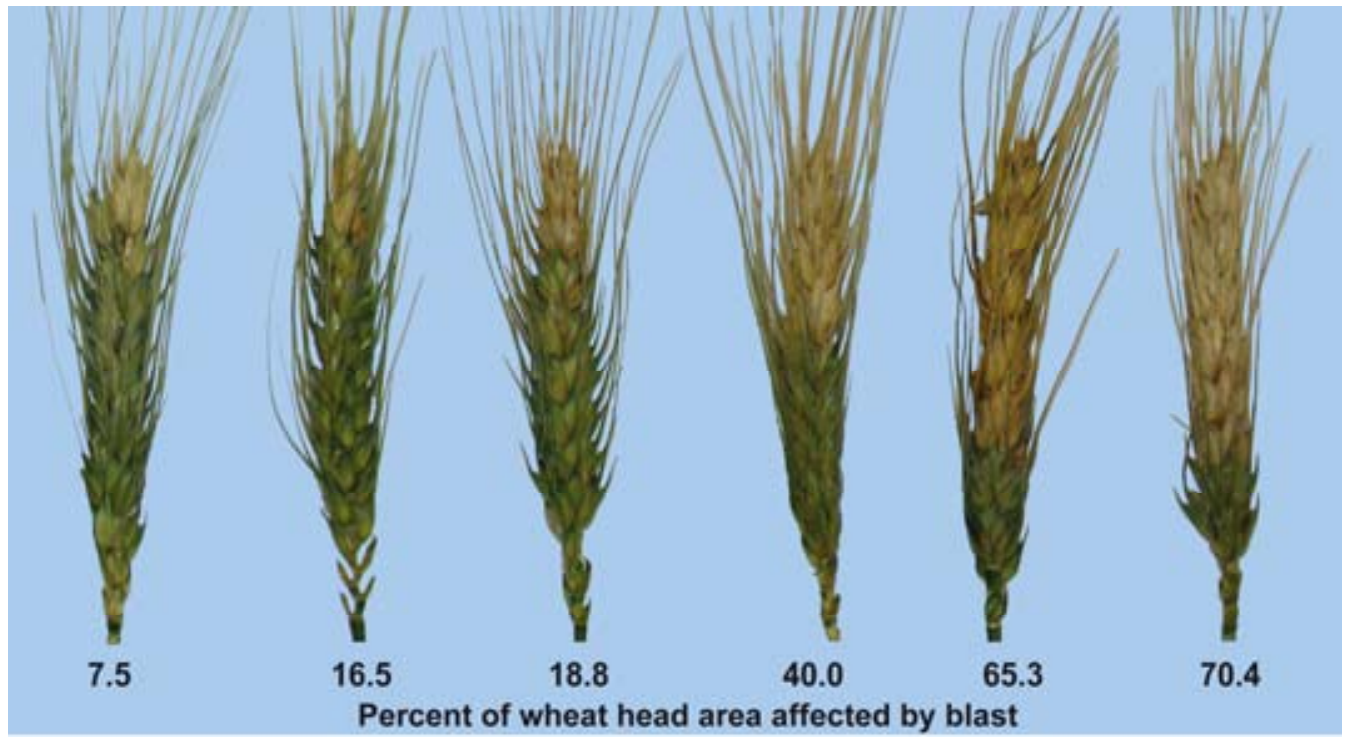

Fig. 1. Variation in blast severity observed on wheat heads at early grain filling stage. The heads were collected at plant growth stages 60 to 70 (54). Evaluation of disease severity was made 6 to 7 days after inoculation. 
Gametic disequilibrium and mating types. The wheatinfecting populations from Distrito Federal and Goiás, Minas Triangle, and São Paulo were at equilibrium but the population from Paraná showed significant gametic disequilibrium
$\left(I_{A}=0.386, P \leq 0.05\right)$ (Table 3). MAT1-1 and MAT1-2 were found in all wheat-infecting populations except São Paulo (Table 3; Supplemental Table 2). However, the ratio was highly skewed toward MAT1-1 in all populations (Table 3). Both mating

TABLE 3. Multilocus microsatellite genotypes (MLMGs) identified in the wheat-infecting populations of Magnaporthe oryzae, genotypic diversity indices, tests for gametic equilibrium, mating types (MAT1-1 and MAT1-2), and distribution of avirulence genes AVR-PITA and AVR1-CO39

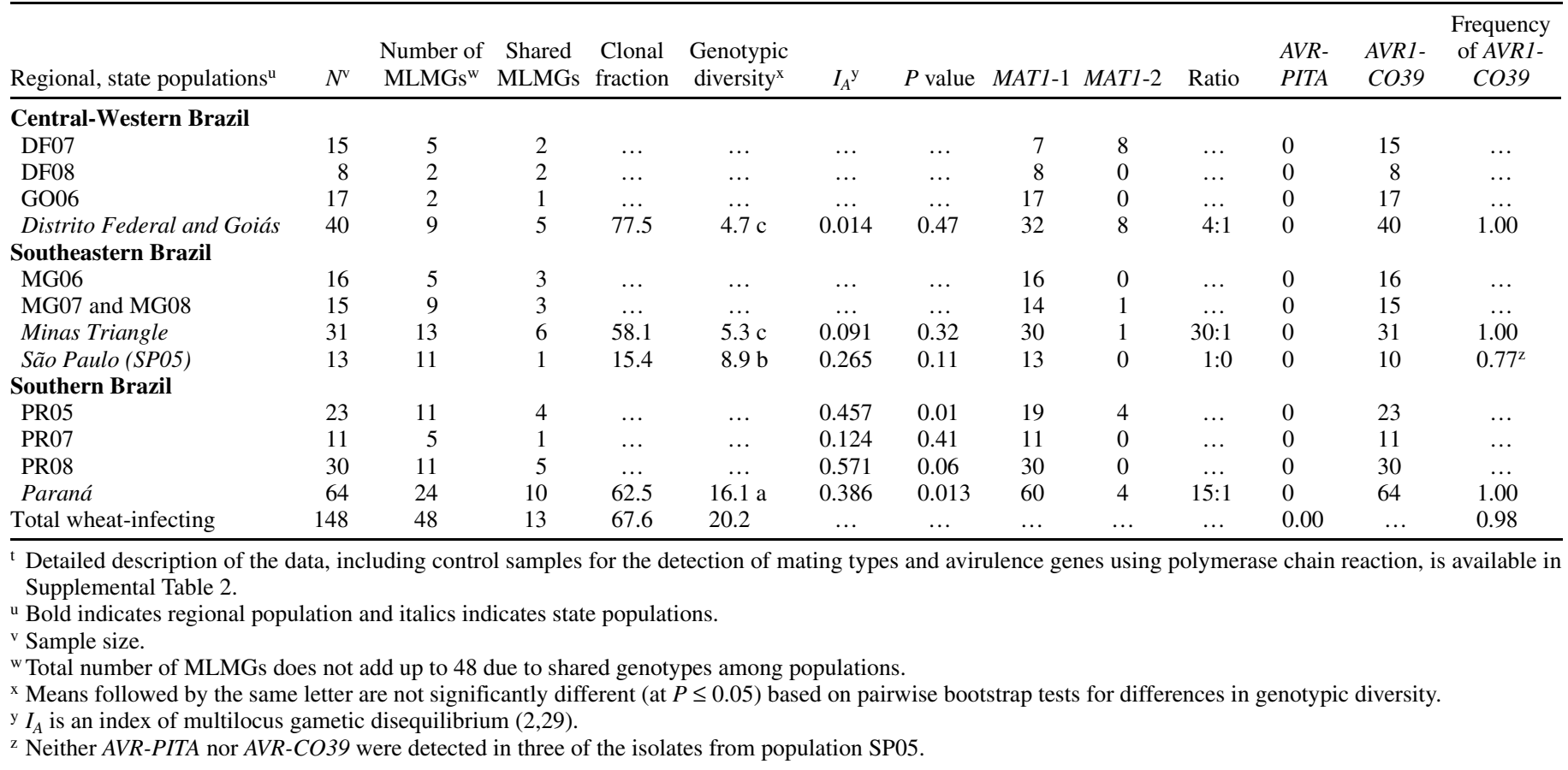

TABLE 4. Hierarchical distribution of gene diversity among Brazilian wheat- and rice-infecting populations of Magnaporthe oryzae ${ }^{2}$

\begin{tabular}{lccc}
\hline Contrasts & df & $\Phi_{\text {statistics }}$ & $P$ \\
\hline Between wheat-infecting and rice-infecting populations & 1 & $\Phi_{\mathrm{CT}}=0.896$ & $\leq 0.001$ \\
Among wheat-infecting populations & 3 & $\Phi_{\mathrm{ST}}=0.027$ & $0.59 \mathrm{NS}$ \\
Among rice-infecting populations & 2 & $\Phi_{\mathrm{ST}}=0.065$ & $0.41 \mathrm{NS}$ \\
\hline
\end{tabular}

${ }^{\mathrm{z}} \mathrm{NS}=$ nonsignificant.

TABLE 5. Measures of differentiation among wheat- and rice-infecting populations of Magnaporthe oryzae from central-southern Brazil based on $\Phi_{\mathrm{ST}}$ values ${ }^{\mathrm{z}}$

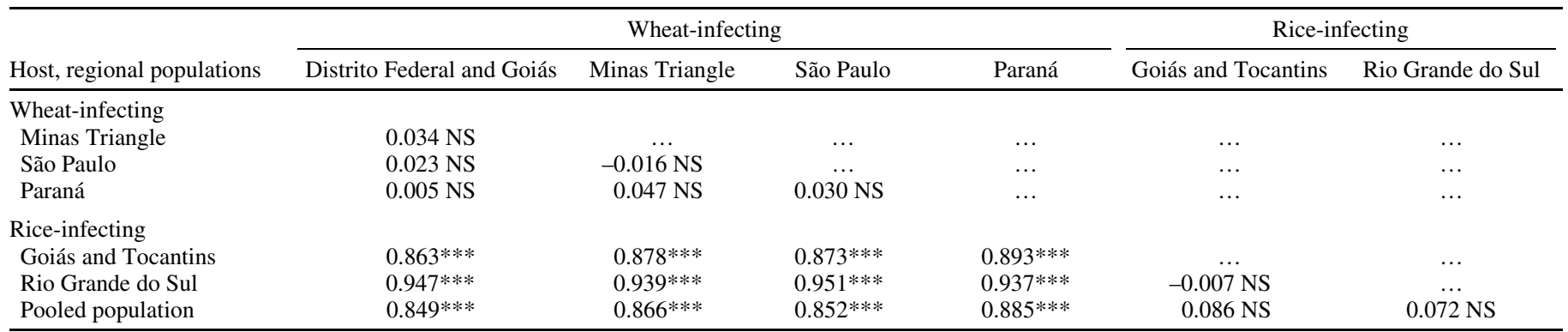

${ }^{\mathrm{z}}$ Pairwise distances computed as the sum of squared size differences between two haplotypes (41). NS $=$ nonsignificant and $* * *=$ significant at $P \leq 0.001$.

TABLE 6. Maximum likelihood estimates of demographic parameters from the divergence between wheat- and rice-infecting populations of Magnaporthe oryzae ${ }^{\mathrm{x}}$

\begin{tabular}{|c|c|c|c|c|}
\hline \multirow[b]{2}{*}{ Populations } & \multirow[b]{2}{*}{ Clone corrected sample size } & \multirow[b]{2}{*}{$\theta(2 \mathrm{Ne} \mu)^{\mathrm{y}}$} & \multicolumn{2}{|c|}{ Migration rate $2 \mathrm{Nm}^{\mathrm{z}}$} \\
\hline & & & Wheat-infecting & Rice-infecting \\
\hline Wheat-infecting & 48 & 1.01 & & $0.28 \mathrm{~A}(0.19-0.40)$ \\
\hline
\end{tabular}


types were found in the rice-infecting isolates included as controls.

Virulence spectrum of $M$. oryzae on wheat seedlings. Isolate and cultivar effects and isolate-cultivar interaction were significant at $P<0.001$ (Table 2, combined ANOVA). Differential responses, including complete resistance, were found on seedlings of the seven tested wheat cultivars. The 69 isolates were classified into 14 seedling virulence groups (SVGs), designated A to $\mathrm{U}$ (Table 7). SVG A, which was virulent on all seven cultivars, included 25 isolates ( $36 \%$ of the total sample). SVG D, avirulent on BRS Buriti and BRS 229, was the second most common virulence group, represented by 24 isolates $(35 \%$ of the tested isolates). SVGs C, E to G, J, M, P, and R were rare, representing each $<2 \%$ of the total sample. SVG U was virulent only on wheat
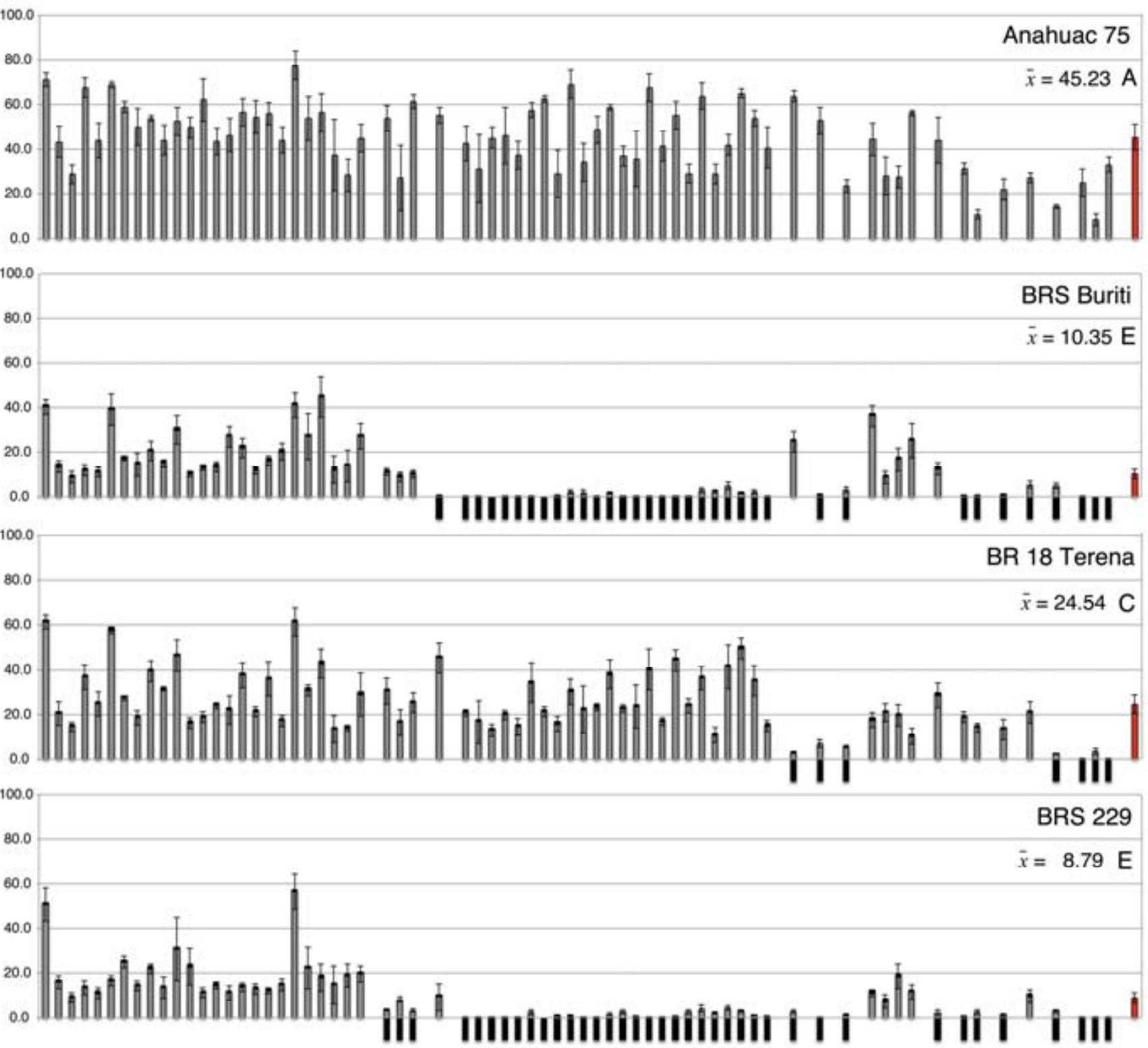

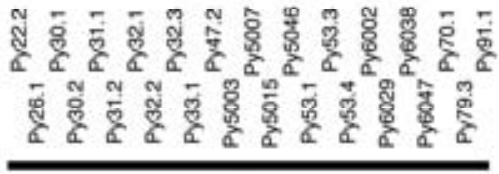

A

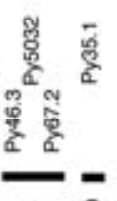

$B$ C

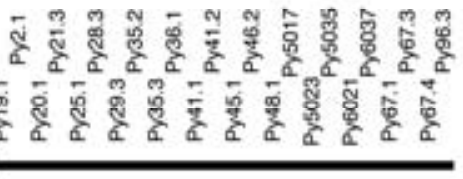

D

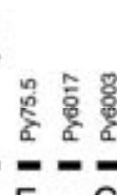

$E_{F} G$

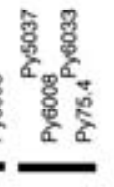

$\mathrm{H}$

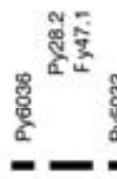

J L

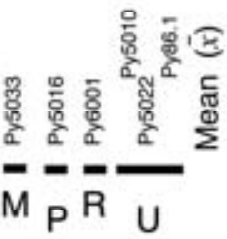

Seedlings virulence groups (SVG) of wheat-infecting Magnaporthe oryzae isolates

(Continued on next page)

Fig. 2. Seedling reaction of seven wheat cultivars and barley 'Pleasant' to 69 isolates of wheat-infecting Magnaporthe oryzae representing 14 virulence groups (A to U). Light gray-shaded columns represent disease severity (percentage of leaf area covered with blast lesions) for each fungal isolate on wheat 'Anahuac 75', 'BRS Buriti', 'BR 18 Terena', 'BRS 229', 'BR 24', 'BRS 220', 'MGS 3 Brilhante', and barley 'Pleasant'. Rice 'Maratelli' was resistant to all wheat-infecting isolates (not included in this figure). Black columns just beneath a gray column represent complete resistance reaction (i.e., $<10 \%$ leaf area affected by blast), while the lack of a column indicates susceptibility. A to U are seedling virulence groups. Vertical bars indicate standard errors of the mean disease severity. Bars to the far right indicate the mean disease severity for each cultivar. Means followed by the same letters are not significantly different by the Scott-Knott test at $P \leq$ 0.05 . 
Anahuac 75. We also detected differences in partial resistance on wheat seedlings, as indicated by the differences in disease severity between 'Anahuac 75' (fully susceptible) and 'BRS 220', 'BR 18 Terena', or 'BR 24' (partially resistant) (Fig. 2). Mean disease severities were $45,24,25$, and $25 \%$, for 'Anahuac 75 ', 'BRS 220', 'BR 18 Terena', and 'BR 24', respectively (significant Scott-Knott test for all three pairwise comparisons between 'Anahuac 75' and the other cultivars at $P \leq 0.05$ ). 'Maratelli' rice was resistant to all wheat-infecting isolates, whereas 'Pleasant' barley was susceptible to all isolates.

Virulence spectrum of $M$. oryzae on detached wheat heads. Isolate and cultivar effects and the isolate-cultivar interaction were all significant at $P<0.001$ (Table 2, combined ANOVA).
The 27 isolates were classified into eight detached-head virulence groups (HVGs), designated $\mathrm{A}^{\prime}$ to $\mathrm{T}^{\prime}$ (Table 7). Fourteen of the isolates were classified as detached HVG A', which was virulent on all seven wheat cultivars. Wheat 'MGS 3 Brilhante' was resistant to seven of the HVGs while 'BR 24' and 'BRS 220' were resistant to five of the HVGs. There was not a strong correlation between seedling and head reactions. Except for five isolates from HVG A' (19\% of the total sample) that were similar to SVG A, all the remaining HVGs had a distinct response on the wheat differentials compared with the SVGs. Although the most resistant cultivars ('MGS 3 Brilhante' and 'BRS 220') had average disease severities of 18 to $24 \%$ of the wheat head affected by blast, the least resistant cultivars ('BRS 229', 'BR 18 Terena', and

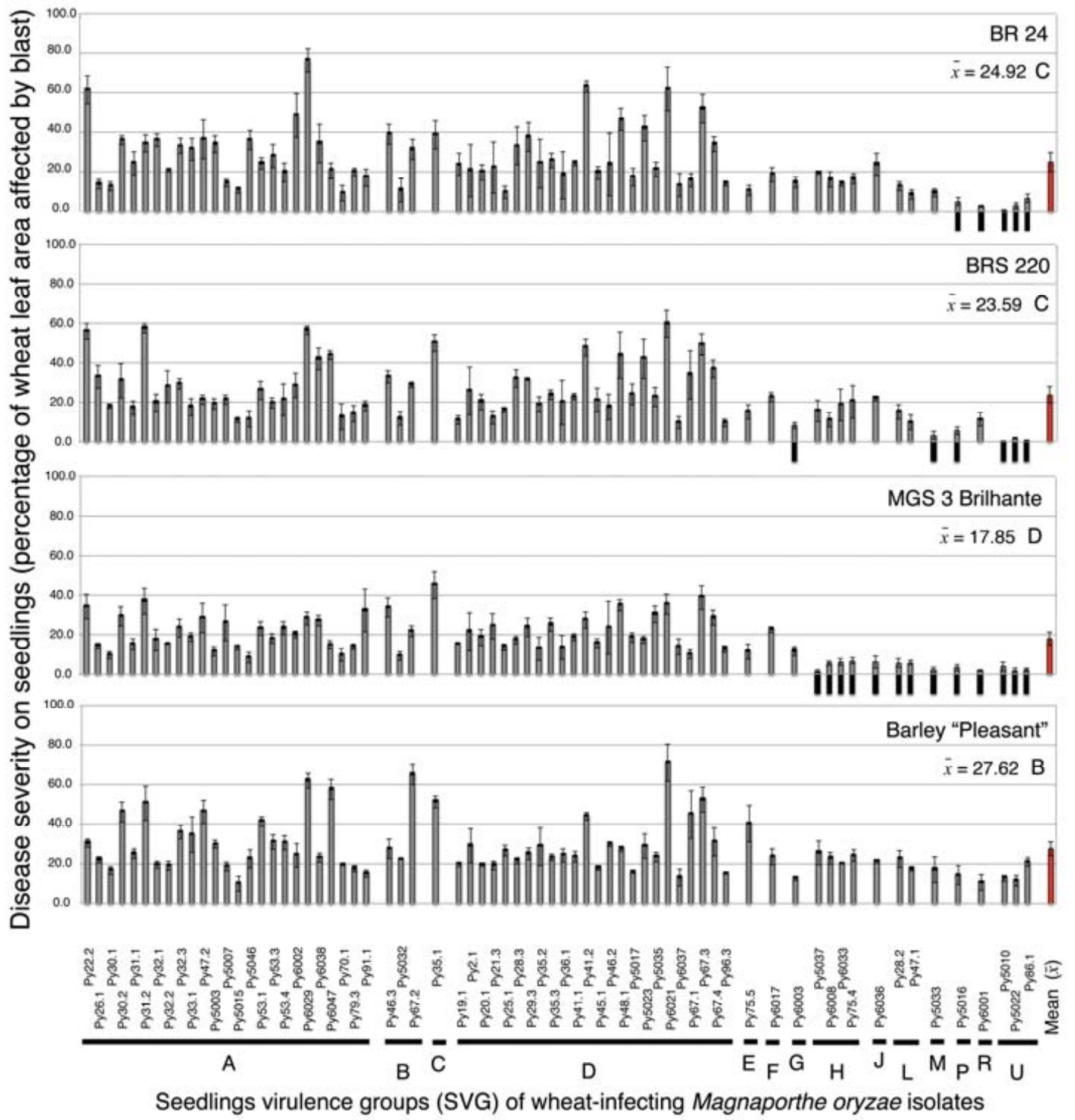

Fig. 2. (Continued from previous page) 


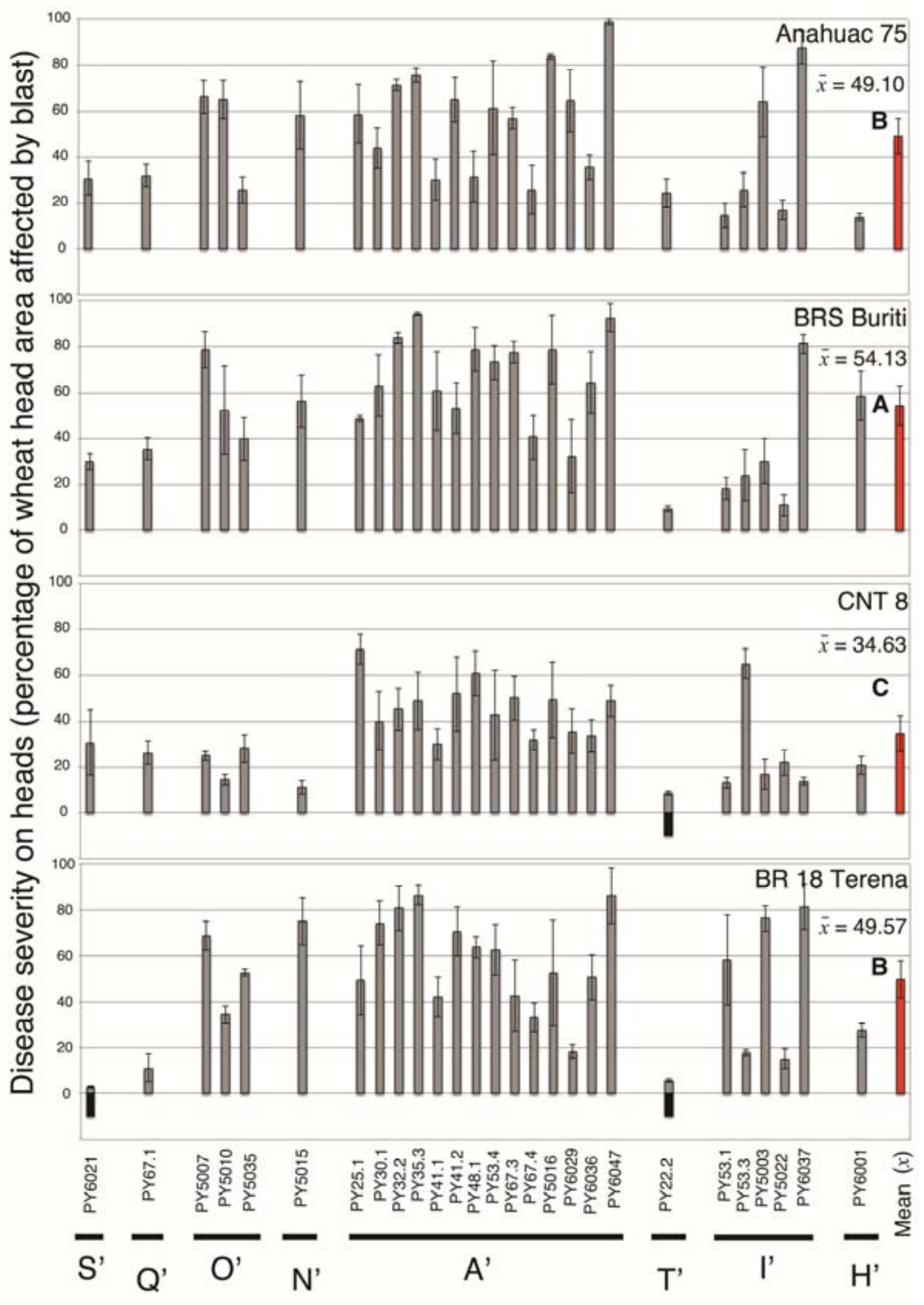

Head virulence groups (HVG) of wheat-infecting Magnaporthe oryzae isolates

(Continued on next page)

Fig. 3. Head reaction of eight wheat cultivars to 27 isolates of wheat-infecting Magnaporthe oryzae representing eight virulence groups $\left(\mathrm{A}^{\prime}\right.$ to $\left.\mathrm{T}^{\prime}\right)$. Light grayshaded columns represent disease severity (percentage of head area covered with blast) for each fungal isolate on wheat 'Anahuac 75', 'BRS Buriti', 'CNT 8', 'BR 18 Terena', 'BRS 229', 'BR 24', 'BRS 220', and 'MGS 3 Brilhante'. Black columns just beneath a gray column represent complete resistance reaction (i.e., <10\% wheat head area affected by blast), while the lack of a column indicates susceptibility. $\mathrm{A}^{\prime}, \mathrm{H}^{\prime}, \mathrm{I}^{\prime}, \mathrm{N}^{\prime}, \mathrm{O}^{\prime}, \mathrm{Q}^{\prime}, \mathrm{S}^{\prime}$, and $\mathrm{T}^{\prime}$ are head virulence groups. Vertical bars indicate standard errors of the mean disease severity. Bars to the far right indicate the mean disease severity for each cultivar. Means followed by the same letter are not significantly different by the Scott-Knott test at $P \leq 0.05$. 


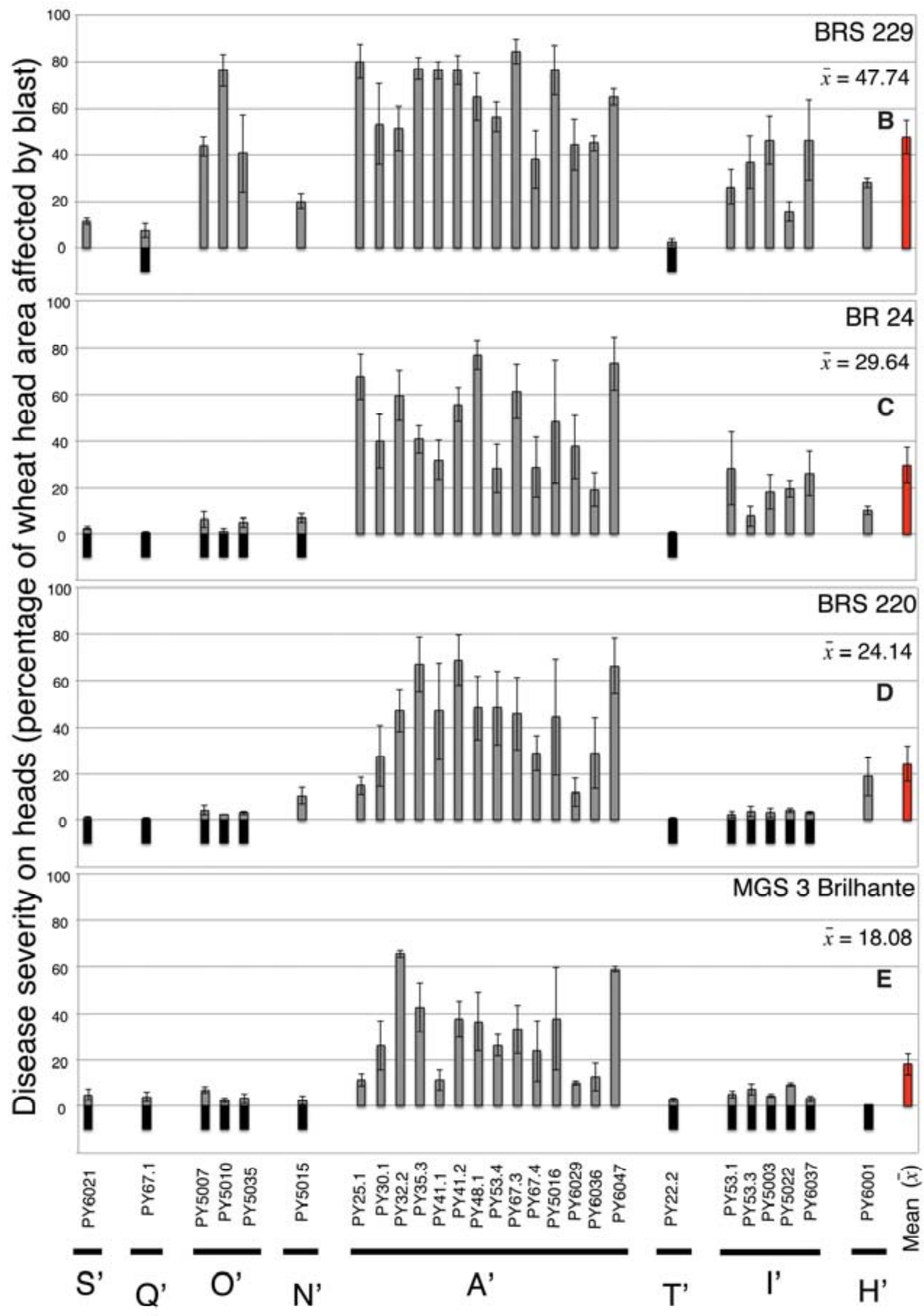

Head virulence groups (HVG) of wheat-infecting Magnaporthe oryzae isolates 
'BRS Buriti') had average disease severities of 48 to $54 \%$. We also detected partial resistance among the tested wheat cultivars, especially 'BR 24' and 'CNT 8', that showed intermediate disease severities of 24 to $35 \%$ (Fig. 3). Scott-Knott tests of pairwise comparisons between the most resistant, the partially resistant, and the least resistant cultivars were significant at $P \leq 0.05$ (Fig. 3).

Geographical distribution of $M$. oryzae virulence groups. SVGs A, D, and $\mathrm{J}$ were detected in all three geographical populations, whereas SVGs $\mathrm{C}$ and $\mathrm{J}$ were restricted to centralwestern Brazil. SVGs F, G, and R were found only in Minas Triangle and SVGs E, M, P, and U were detected only in southern Brazil. HVGs $\mathrm{A}^{\prime}$ and $\mathrm{I}^{\prime}$ were detected in all three populations whereas $\mathrm{H}^{\prime}$ and $\mathrm{S}^{\prime}$ were restricted to Minas Triangle and $\mathrm{N}^{\prime}, \mathrm{O}^{\prime}$, $\mathrm{Q}^{\prime}$, and $\mathrm{T}^{\prime}$ were detected only in Paraná, southern Brazil. Paraná had the highest number of both SVGs and HVGs (Fig. 4).

Presence or absence of avirulence genes AVR-Pita and AVR1-Co39. All of the wheat-infecting isolates lacked the $A V R$ $P I T A$ gene (Table 3), whereas AVR-PITA was detected in the riceinfecting control isolates. AVRI-CO39 was detected in $98 \%$ of the wheat-infecting isolates (with the only exceptions in São Paulo) but was not amplified from the rice-infecting control isolates.

\section{DISCUSSION}

We report here the first population genetic analysis of the wheat blast pathogen $M$. oryzae since it emerged in Brazil $\approx 25$ years ago. Our results indicate that the pathogen has a mixed reproductive system, displays a high degree of gene and genotype flow across large spatial scales, and exhibits significant pathotype diversity. These properties are consistent with a high evolutionary potential.

The origins of wheat blast. We compared sympatric wheatand rice-infecting populations of $M$. oryzae from Brazil to test the hypothesis that wheat blast emerged as a wheat-specialized population from the $M$. oryzae population infecting rice in Brazil. An earlier report based on cross pathogenicity data (50) suggested that there may be two different pathogen populations infecting wheat, one that could have originated from rice and another that originated from a second, unidentified source. High population differentiation was found between wheat- and rice-infecting populations of $M$. oryzae, with very little historical migration inferred between the two populations. Almost all of the wheatinfecting isolates carried AVRI-CO39, which would predict avirulence on Oryza spp., and all 69 wheat-infecting isolates tested in our study were avirulent on Maratelli rice. This finding of very low historical migration and avirulence on rice suggests that the Brazilian wheat-infecting population was derived exclusively from an as-yet-unknown Poaceae-infecting M. oryzae population.

Long-distance gene flow 25 years after the first epidemics. The population genetic structure was consistent with high levels of gene flow across a large spatial scale. The three most common $M$. oryzae virulence groups were present at similar frequencies among the geographical regions. We postulate that the high levels of gene flow among the four geographically distant populations are due mainly to two mechanisms (i) man-mediated movement of infested seed and (ii) efficient long-distance dispersal of the pathogen via airborne inoculum. Because wheat blast usually affects heads, infected wheat seed have long been considered the main source of primary inoculum and long-distance dispersal $(19,49)$. The percentage of infected seed found in naturally infested wheat fields was 68 to $83 \%$ (48). Therefore, improved seed testing was recommended by the Brazilian agricultural research service (20) and seed treatment with eradicant fungicides is warranted to prevent long-distance dispersal throughout the wheat growing areas in Brazil (19). Urashima et al. (51) provided evidence that $M$. oryzae conidia can be dispersed at least $1,000 \mathrm{~m}$ from an infected field site. The largest distance between our sampled sites was $1,065 \mathrm{~km}$. Though 25 years have passed since the first recorded wheat blast epidemics in Paraná State, it remains unclear whether the pathogen could have covered this distance solely through air dispersal following a multidimensional

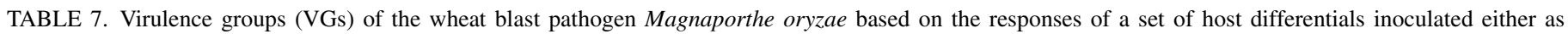
seedlings or as detached heads ${ }^{\mathrm{y}}$

\begin{tabular}{|c|c|c|c|c|c|c|c|c|c|c|c|c|}
\hline \multirow[b]{2}{*}{$\mathrm{VG}^{\mathrm{z}}$} & \multicolumn{8}{|c|}{ Wheat } & \multirow{2}{*}{$\frac{\text { Barley }}{\text { Pleasant }}$} & \multirow{2}{*}{$\frac{\text { Rice }}{\text { Maratelli }}$} & \multicolumn{2}{|c|}{ Isolates } \\
\hline & Anahuac 75 & BR 24 & MGS 3 Brilhante & BR 18 Terena & BRS 220 & BRS Buriti & BRS 229 & CNT-8 & & & $N$ & $\%$ \\
\hline \multicolumn{13}{|c|}{ Seedling } \\
\hline A & $\mathrm{S}$ & $\mathrm{S}$ & $\mathrm{S}$ & $S$ & $\mathrm{~S}$ & $\mathrm{~S}$ & S & ND & $\mathrm{S}$ & $\mathbf{R}$ & 25 & 36.2 \\
\hline $\mathrm{B}$ & $\mathrm{S}$ & $\mathrm{S}$ & $\mathrm{S}$ & S & S & $\mathrm{S}$ & $\mathbf{R}$ & ND & $\mathrm{S}$ & $\mathbf{R}$ & 3 & 4.3 \\
\hline $\mathrm{C}$ & $\mathrm{S}$ & $\mathrm{S}$ & $\mathrm{S}$ & $\mathrm{S}$ & $\mathrm{S}$ & $\mathbf{R}$ & $\mathrm{S}$ & ND & $\mathrm{S}$ & $\mathbf{R}$ & 1 & 1.4 \\
\hline $\mathrm{D}$ & $\mathrm{S}$ & $\mathrm{S}$ & $\mathrm{S}$ & $\mathrm{S}$ & S & $\mathbf{R}$ & $\mathbf{R}$ & ND & $\mathrm{S}$ & $\mathbf{R}$ & 24 & 34.8 \\
\hline $\mathrm{E}$ & $\mathrm{S}$ & $\mathrm{S}$ & $\mathrm{S}$ & $\mathbf{R}$ & $\mathrm{S}$ & $\mathrm{S}$ & $\mathbf{R}$ & ND & $\mathrm{S}$ & $\mathbf{R}$ & 1 & 1.4 \\
\hline $\mathrm{F}$ & $\mathrm{S}$ & $\mathrm{S}$ & $\mathrm{S}$ & $\mathbf{R}$ & $\mathrm{S}$ & $\mathbf{R}$ & $\mathbf{R}$ & ND & $\mathrm{S}$ & $\mathbf{R}$ & 1 & 1.4 \\
\hline $\mathrm{G}$ & $\mathrm{S}$ & $\mathrm{S}$ & $\mathrm{S}$ & $\mathbf{R}$ & $\mathbf{R}$ & $\mathbf{R}$ & $\mathbf{R}$ & ND & $\mathrm{S}$ & $\mathbf{R}$ & 1 & 1.4 \\
\hline $\mathrm{H}$ & $\mathrm{S}$ & $\mathrm{S}$ & $\mathbf{R}$ & $\mathrm{S}$ & $\mathrm{S}$ & $\mathrm{S}$ & $\mathrm{S}$ & ND & $\mathrm{S}$ & $\mathbf{R}$ & 4 & 5.8 \\
\hline $\mathrm{J}$ & $\mathrm{S}$ & $\mathrm{S}$ & $\mathbf{R}$ & $\mathrm{S}$ & $\mathrm{S}$ & $\mathrm{S}$ & $\mathbf{R}$ & ND & $\mathrm{S}$ & $\mathbf{R}$ & 1 & 1.4 \\
\hline $\mathrm{L}$ & $\mathrm{S}$ & $\mathrm{S}$ & $\mathbf{R}$ & $\mathrm{S}$ & $\mathrm{S}$ & $\mathbf{R}$ & $\mathbf{R}$ & ND & $\mathrm{S}$ & $\mathbf{R}$ & 2 & 2.9 \\
\hline M & $\mathrm{S}$ & $\mathrm{S}$ & $\mathbf{R}$ & $\mathrm{S}$ & $\mathbf{R}$ & $\mathbf{R}$ & $\mathbf{R}$ & ND & $\mathrm{S}$ & $\mathbf{R}$ & 1 & 1.4 \\
\hline $\mathrm{P}$ & $\mathrm{S}$ & $\mathbf{R}$ & $\mathbf{R}$ & $\mathrm{S}$ & $\mathbf{R}$ & $\mathbf{R}$ & $\mathrm{S}$ & ND & $\mathrm{S}$ & $\mathbf{R}$ & 1 & 1.4 \\
\hline $\mathrm{R}$ & $\mathrm{S}$ & $\mathbf{R}$ & $\mathbf{R}$ & $\mathbf{R}$ & $\mathrm{S}$ & $\mathbf{R}$ & $\mathbf{R}$ & ND & $\mathrm{S}$ & $\mathbf{R}$ & 1 & 1.4 \\
\hline $\mathrm{U}$ & $\mathrm{S}$ & $\mathbf{R}$ & $\mathbf{R}$ & $\mathbf{R}$ & $\mathbf{R}$ & $\mathbf{R}$ & $\mathbf{R}$ & ND & $\mathrm{S}$ & $\mathbf{R}$ & 3 & 4.3 \\
\hline Total & $\ldots$ & $\ldots$ & $\ldots$ & $\ldots$ & $\ldots$ & $\ldots$ & $\ldots$ & ND & $\ldots$ & $\ldots$ & 69 & 100 \\
\hline \multicolumn{13}{|l|}{ Head } \\
\hline $\mathrm{A}^{\prime}$ & $\mathrm{S}$ & $\mathrm{S}$ & $\mathrm{S}$ & $\mathrm{S}$ & $\mathrm{S}$ & $\mathrm{S}$ & $S$ & $\mathrm{~S}$ & ND & ND & 14 & 51.9 \\
\hline $\mathrm{H}^{\prime}$ & $\mathrm{S}$ & $\mathrm{S}$ & $\mathbf{R}$ & $\mathrm{S}$ & $\mathrm{S}$ & $\mathrm{S}$ & $\mathrm{S}$ & $\mathrm{S}$ & ND & ND & 1 & 3.7 \\
\hline $\mathrm{I}^{\prime}$ & $\mathrm{S}$ & $\mathrm{S}$ & $\mathbf{R}$ & $\mathrm{S}$ & $\mathbf{R}$ & $\mathrm{S}$ & $\mathrm{S}$ & $\mathrm{S}$ & ND & ND & 5 & 18.5 \\
\hline $\mathrm{N}^{\prime}$ & $\mathrm{S}$ & $\mathbf{R}$ & $\mathbf{R}$ & $\mathrm{S}$ & $\mathrm{S}$ & $\mathrm{S}$ & $\mathrm{S}$ & $\mathrm{S}$ & ND & ND & 1 & 3.7 \\
\hline $\mathrm{O}^{\prime}$ & $\mathrm{S}$ & $\mathbf{R}$ & $\mathbf{R}$ & $\mathrm{S}$ & $\mathbf{R}$ & $\mathrm{S}$ & $\mathrm{S}$ & $\mathrm{S}$ & ND & ND & 3 & 11.1 \\
\hline $\mathrm{Q}^{\prime}$ & $\mathrm{S}$ & $\mathbf{R}$ & $\mathbf{R}$ & $\mathrm{S}$ & $\mathbf{R}$ & $S$ & $\mathbf{R}$ & $\mathrm{S}$ & ND & ND & 1 & 3.7 \\
\hline $\mathrm{S}^{\prime}$ & $\mathrm{S}$ & $\mathbf{R}$ & $\mathbf{R}$ & $\mathbf{R}$ & $\mathbf{R}$ & $S$ & $\mathrm{~S}$ & $\mathrm{~S}$ & ND & ND & 1 & 3.7 \\
\hline $\mathrm{T}^{\prime}$ & $\mathrm{S}$ & $\mathbf{R}$ & $\mathbf{R}$ & $\mathbf{R}$ & $\mathbf{R}$ & $S$ & $\mathbf{R}$ & $\mathbf{R}$ & ND & ND & 1 & 3.7 \\
\hline Total & $\ldots$ & $\ldots$ & $\ldots$ & $\ldots$ & $\ldots$ & $\ldots$ & $\ldots$ & $\ldots$ & ND & ND & 27 & 100.0 \\
\hline
\end{tabular}

${ }^{\mathrm{y}} \mathrm{R}$ (bold) and $\mathrm{S}$ indicate resistant or susceptible reactions, respectively. ND $=$ not determined.

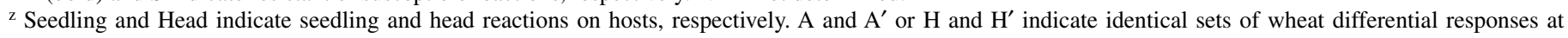
seedling and head stages. All the remaining head VGs had no overlapping set of differentials that showed a response similar to a seedling virulence group. 
stepping-stone migration model (26). It remains possible that airborne ascospores resulting from the sexual stage have contributed to long-distance dissemination of the pathogen.

Evidence for a mixed reproductive mode. The expectations for fungi that regularly undergo sexual recombination are high genotypic diversity, low clonal fraction, neutral markers at gametic equilibrium, and mating types distributed at similar frequencies $(30,32)$. Earlier work provided support for the hypothesis that sexual recombination occurs in field populations of the wheat-infecting $M$. oryzae: fungal populations had high diversity, both mating types were detected within field populations, and isolates had high fertility and crossing ability $(9,47,49,50)$. Thus, we postulated that populations of wheat-infecting $M$. oryzae could be random mating and sexually recombining in nature, with ascospores providing an important source of primary inoculum for both local and long-distance dispersal. Instead, we found evidence for a mixed reproductive system characterized by both sexual and asexual reproduction.

Both mating types were found in all populations except São Paulo, but MAT1-1 predominated in all populations, indicating that the potential for sexual reproduction occurs in most populations but that formation of the sexual stage may be episodic in-

\section{A Seedling virulence groups (SVG)}
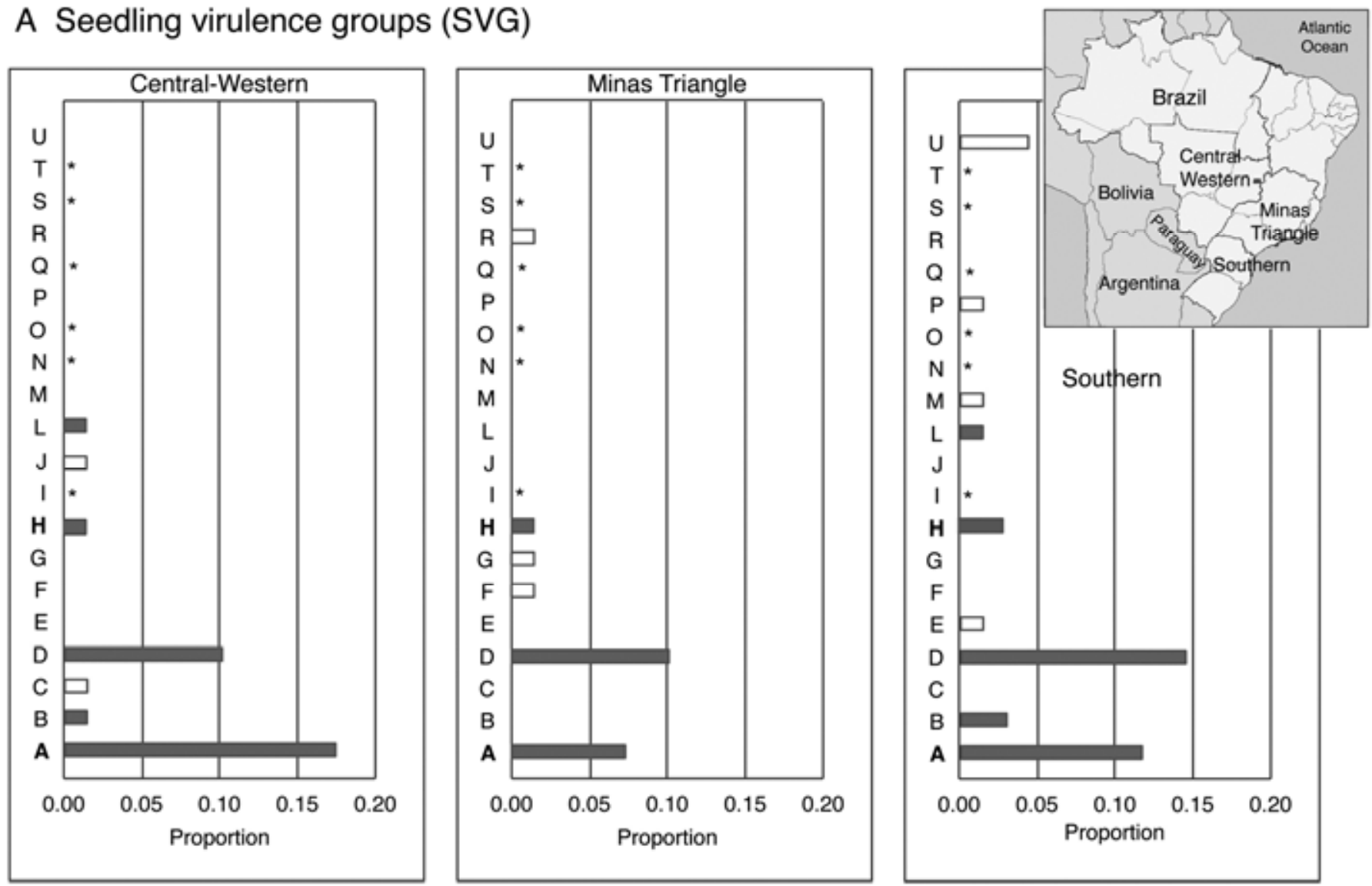

\section{B Head virulence groups (HVG)}
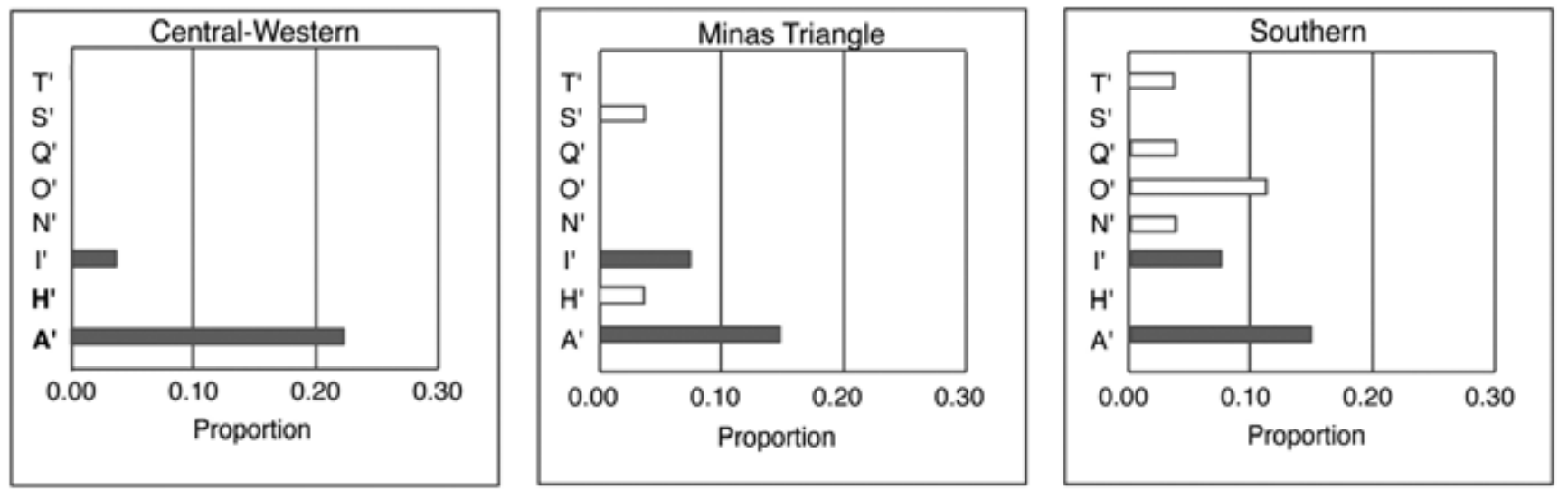

Fig. 4. Distribution of virulence groups of the wheat blast pathogen Magnaporthe oryzae in central-southern Brazil. Capital letters at the y-axis represent either A, seedling virulence groups (SVGs) or B, head virulence groups (HVGs). Bar length indicates the proportion of each virulence group in Central-Western, Minas Triangle, and Southern Brazil. Gray shaded bars indicate shared virulence groups between regions and * indicates virulence groups characterized by a set of wheat differentials response only detected at the heading stage. $N=69$ isolates for SVG and 27 isolates for HVG. 
stead of recurring on an annual basis. For comparison, the wheat pathogens Zymoseptoria tritici and Phaeosphaeria nodorum also exhibit mixed reproductive systems but maintain a 1:1 ratio of the two mating types across all spatial scales because sexual recombination happens at least once per year $(42,55)$. The presence of both mating types in a population could indicate historical recombination but is not, in itself, an indicator of contemporary sexual reproduction (12).

Despite the skewed ratio in mating type frequencies, gametic equilibrium was found in three of four M. oryzae populations. In the Paraná population that was in disequilibrium, gametic equilibrium was found in two of its component subpopulations after analyzing each sampling year separately (Table 3 ). Based on these findings, we propose that ascospores may be a significant source of inoculum for wheat blast epidemics in Brazil. We further propose that novel pathogen genotypes produced by sexual recombination may be favored by selection and increase in frequency via asexual reproduction within each field, spreading as clones over short distances via conidia and over longer distances via contaminated seed. This scenario would explain the clonal fractions observed in most populations as well as the shared MLMGs among populations.

According to a risk model proposed earlier (30), the capacity for long-distance gene and genotype flow and the mixed reproductive system place $M$. oryzae in the pathogen category with the highest evolutionary potential, suggesting that control strategies based on systemic fungicides or major resistance genes should be implemented carefully to avoid the emergence of fungicide resistance or the breakdown of disease resistance by the emergence of virulence, as demonstrated experimentally by Urashima et al. (46).

Diversity for virulence in Brazilian wheat-infecting $\boldsymbol{M}$. oryzae strains. We found evidence for diversity in virulence and in differential response of wheat cultivars to challenge by the wheat blast pathogen. We detected both complete and partial resistance in seven Brazilian wheat cultivars at both seedling and head stages of development. The 69 fungal isolates representing 38 distinct MLMGs could be differentiated into 14 SVGs, while 27 of these isolates were differentiated into eight HVGs (Table 7). Partial resistance to wheat blast was also detected in several cultivars, notably 'BRS 220', 'BR 18 Terena', and 'BR 24' at the seedling stage and 'BRS 24' at the heading stage (Figs. 1 and 2). We postulate that the high frequencies of SVG A and HVG A' are a result of their broader virulence, while SVGs F, G, M, P, and R and HVGs $\mathrm{S}^{\prime}, \mathrm{Q}^{\prime}$, and $\mathrm{T}^{\prime}$ occur at a lower frequencies because they lack virulence on some wheat cultivars. The uniform susceptibility of 'Pleasant' barley indicates that barley may provide an important source of inoculum that could fuel wheat blast epidemics in Brazil.

This is the first comprehensive study to use detached wheat heads to assess cultivar resistance and the diversity of virulence for the wheat blast pathogen on a population scale. Similar studies with detached heads were used to assess the reaction of wheat to infection by Fusarium graminearum transformed with the greenflorescent protein gene $(24,36)$. Recently, Cruz and co-workers (13) reported a preliminary study using detached wheat heads to assess the reaction of 85 U.S. wheat cultivars to a single Brazilian pathotype of the wheat blast pathogen. Although earlier studies indicated that some of the wheat cultivars grown in Brazil showed resistance to wheat blast at the heading stage $(14,15,27)$, none of them showed resistance against all of the $M$. oryzae pathotypes used in our study. As observed in both the seedling and heading assays, there was a continuous variation in head blast severity among the tested wheat cultivars, as also reported by Cruz and coworkers (13). This indicates that quantitative resistance is likely operating in this pathosystem in both leaves and ears.

The frequent occurrence of susceptible reactions to wheat blast using both seedling and adult plant assays on the majority of wheat genotypes currently grown in Brazil has led to the misconception that seedling and adult plant reactions are correlated. However, our experiments showed that seedling and adult responses are not correlated. As examples, isolates Py05010 and Py05022 belong to SVG U and HVGs $\mathrm{O}^{\prime}$ or I'. 'BRS18' and 'BRS Buriti' were both resistant to these isolate as seedlings but they were susceptible to them at the heading stage. Detached heads of 'BRS Buriti' were susceptible to all 27 isolates of $M$. oryzae tested but, at the seedling stage, it was resistant to isolates in SVG C, D, F, G, L, M, P, R, and U (Table 7; Figs. 1 and 2). Cruz and co-workers (13) also reported that seedling infection was not reliable in predicting the severity of head infection in a cultivar. Consequently, selection and breeding for wheat blast resistance should include assays of both young and mature plant stages to the most common virulence groups in the country.

\section{ACKNOWLEDGMENTS}

This work was partially funded by an ETH grant (TH-16/06-1), a research fellowship (Pq-2 308394 / 2009-7 and 307361/2012-8), a grant (504073/2011-7) from the Brazilian National Council for Scientific and Technological Development $(\mathrm{CNPq})$ and from São Paulo Research Foundation, Brazil (FAPESP 2013/10655-4 and 2013/10795-0) to P. C. Ceresini. V. L. Castroagudin is supported by a PDJ research fellowship from CNPq (150490/2013-5). The statistical analyses on migration patterns and admixture were carried out using the resources of the Computational Biology Service Unit from Cornell University (http:// cbsuapps.tc.cornell.edu/index.aspx), which is partially funded by Microsoft Corporation. The microsatellite data were collected using the facilities of the Genetic Diversity Center at the ETH. J. L. N. Maciel and P. C. Ceresini contributed equally to this manuscript. J. L. N. Maciel thanks C. D. M. Nunes (Embrapa Temperate Agriculture), G. D. Funck (Instituto Rio-Grandense do Arroz, IRGA), and M. E. Ferreira (Embrapa Genetic Resources and Biotechnology, Cenargen) for providing Magnaporthe oryzae isolates.

\section{LITERATURE CITED}

1. Adreit, H., Santoso, Andriantsimialona, D., Utami, D. W., Notteghem, J. L., Lebrun, M. H., and Tharreau, D. 2007. Microsatellite markers for population studies of the rice blast fungus, Magnaporthe grisea. Mol. Ecol. Notes 7:667-670.

2. Agapow, P.-M., and Burt, A. 2001. Indices of multilocus linkage disequilibrium. Mol. Ecol. Notes 1:101-102.

3. Anjos, J. R. N., and Charchar, M. J. A. 2000. Natural infection of barley by Pyricularia grisea in Brazil. Fitopatol. Bras. 25:205.

4. Anjos, J. R. N., Silva, D. B., Charchar, M. J. D., and Rodrigues, G. C. 1996. Ocorrência de brusone (Pyricularia grisea) em trigo e centeio na região dos cerrados do Brasil Central. Pesqui. Agropecu. Bras. 31:79-82.

5. Averna-Sacca, R. 1912. "Brusone" do arroz. Bol. Agric. 13a:291-302.

6. Azevedo, J. L., and Costa, S. O. P. 1973. Exercícios práticos de genética. Editora Nacional and EDUSP, São Paulo, SP, Brazil.

7. Beerli, P., and Felsenstein, J. 2001. Maximum likelihood estimation of a migration matrix and effective population sizes in $n$ subpopulations by using a coalescent approach. Proc. Natl. Acad. Sci. USA 98:4563-4568.

8. Bonman, J. M., Vergel de Dios, T. I., and Khin, M. M. 1986 Physiologic specialization of Pyricularia oryzae in the Philippines. Plant Dis. 70:767769.

9. Bruno, A. C., and Urashima, A. S. 2001. Inter-relação sexual de Magnaporthe grisea do trigo e de outros hospedeiros. Fitopatol. Bras. 26:21-26.

10. CONAB. 2010. Acompanhamento da safra brasileira: Grãos: Safra 2009/2010, décimo primeiro levantamento. CONAB, Brasília, DF.

11. Consolo, V., Cordo, C., and Salerno, G. 2005. Mating-type distribution and fertility status in Magnaporthe grisea populations from Argentina. Mycopathologia 160:285-290.

12. Couch, B. C., Fudal, I., Lebrun, M.-H., Tharreau, D., Valent, B., van Kim, P., Notteghem, J.-L., and Kohn, L. M. 2005. Origins of host-specific populations of the blast pathogen Magnaporthe oryzae in crop domestication with subsequent expansion of pandemic clones on rice and weeds of rice. Genetics 170:613-630.

13. Cruz, C. D., Bockus, W. W., Stack, J. P., Tang, X., Valent, B. S., Pedley, K. F., and Peterson, G. L. 2012. Preliminary assessment of resistance among U.S. wheat cultivars to the Triticum pathotype of Magnaporthe oryzae. Plant Dis. 96:1501-1505. 
14. Cruz, M. F., Maciel, J. L. N., Prestes, A. M., Bombonatto, E. A. S., Pereira, J. F., and Consoli, L. 2009. Caracterização genética e fenotípica de isolados de Pyricularia grisea do trigo. Trop. Plant Pathol. 34:393401.

15. Cruz, M. F., Prestes, A. M., Maciel, J. L. N., and Scheeren, P. L. 2010. Resistência parcial à brusone de genótipos de trigo comum e sintético nos estádios de planta jovem e de planta adulta. Trop. Plant Pathol. 35:24-31.

16. Duveiller, E., Hodson, D., and Tiedmann, A. 2010. Wheat blast caused by Magnaporthe grisea: A reality and new challenge for wheat research. Page 247-248 in: Abstr. 8th. Int. Wheat Conf. Vavilov Res. Inst. Plant Ind., St. Petersburg, Russia.

17. Excoffier, L., Laval, G., and Schneider, S. 2005. Arlequin (version 3.0): An integrated software package for population genetics data analysis. Evol. Bioinf. Online 1:47-50.

18. Excoffier, L., Smouse, P. E., and Quattro, J. M. 1992. Analysis of molecular variance inferred from metric distances among DNA haplotypes: Application to human mitochondrial DNA restriction data. Genetics 131:479-491.

19. Goulart, A. C. P., Paiva, F. A., and Andrade, P. J. M. 1995. Relação entre a incidência da brusone em espigas de trigo e a presença de Pyricularia grisea nas sementes colhidas. Fitopatol. Bras. 20:184-189.

20. Goulart, A. C. P., Paiva, F. A., and Andrade, P. J. M. 1995. Qualidade sanitária de sementes de trigo produzidos no Mato Grosso do Sul, safras 1987 a 1992. Summa Phytopathol. 21:235-238.

21. Goulart, A. C. P., Sousa, P. G., and Urashima, A. S. 2007. Damages in wheat caused by infection of Pyricularia grisea. Summa Phytopathol. 33:358-363.

22. Grünwald, N. J., Goodwin, S. B., Milgroom, M. G., and Fry, W. E. 2003. Analysis of genotypic diversity data for populations of microorganisms. Phytopathology 93:738-746.

23. Igarashi, S., Utiamada, C. M., Igarashi, L. C., Kazuma, A. H., and Lopes, R. S. 1986. Pyricularia em trigo. 1. Ocorrência de Pyricularia sp. no estado do Paraná. Fitopatol. Bras. 11:351-352.

24. Jansen, C., von Wettstein, D., Schafer, W., Kogel, K. H., Felk, A., and Maier, F. J. 2005. Infection patterns in barley and wheat spikes inoculated with wild-type and trichodiene synthase gene disrupted Fusarium graminearum Proc. Natl. Acad. Sci. USA 102:16892-16897.

25. Kaye, C., Milazzo, J., Rozenfeld, S., Lebrun, M.-H., and Tharreau, D. 2003. The development of simple sequence repeat markers for Magnaporthe grisea and their integration into an established genetic linkage map. Fungal Genet. Biol. 40:207-214.

26. Kimura, M., and Weiss, G. H. 1964. The stepping stone model of population structure and the decrease of genetic correlation with distance. Genetics 49:561-576.

27. Maciel, J. L. N., Paludo, E. A., Só e Silva, M., Scheeren, P. L., and Caierão, E. 2008. Reação à brusone de genótipos de trigo do programa de melhoramento da Embrapa Trigo no estádio de planta adulta. Embrapa Trigo, Passo Fundo, RS, Brazil.

28. Manly, B. F. J. 1991. Randomization and Monte Carlo Methods in Biology. Chapman \& Hall, London.

29. Maynard Smith, J., Smith, N. H., O’Rourke, M., and Spratt, B.G. 1993. How clonal are bacteria? Proc. Natl. Acad. Sci. USA 90:4384-4388.

30. McDonald, B. A., and Linde, C. 2002. Pathogen population genetics, evolutionary potential, and durable resistance. Annu. Rev. Phytopathol. 40:349-379.

31. Meirmans, P. G., and Van Tienderen, P. H. 2004. Genotype and genodive: Two programs for the analysis of genetic diversity of asexual organisms. Mol. Ecol. Notes 4:792-794.

32. Milgroom, M. G. 1996. Recombination and the multilocus structure of fungal populations. Annu. Rev. Phytopathol. 34:457-477.

33. Ou, S. H. 1985. Blast. In: Rice Diseases. S. H. Ou, ed. CAB International, Wallingford, UK.

34. Pontecorvo, G., Roper, J. A., Chemmons, L. M., MacDonald, K. D., and Bufton, A. W. J. 1953. The genetics of Aspergillus nidulans. Adv. Genet. 5:141-238.

35. Prabhu, A. S., Araujo, L. G., Faustina, C., and Berni, R. F. 2003.
Estimativa de danos causados pela brusone na produtividade de arroz de terras altas. Pesqui. Agropecu. Bras. 38:1045-1051.

36. Proctor, R. H., Hohn, T. M., and McCormick, S. P. 1995. Reduced virulence of Gibberella zeae caused by disruption of a trichothecene toxin biosynthetic gene. Mol. Plant-Microbe Interact. 8:593-601.

37. Schneider, C. A., Rasband, W. S., and Eliceiri, K. W. 2012. NIH Image to ImageJ: 25 years of image analysis. Nat. Methods 9:671-675.

38. Scott, A. J., and Knott, M. 1974. A cluster analysis method for grouping means in the analysis of variance. Biometrics 30:507-512.

39. Silva, F. A. S., and Azevedo, C. A. V. 2002. Versão do programa computacional Assistat para o sistema operacional Windows. Rev. Bras. Prod. Agroind. 4:71-78.

40. Silva, F. A. S., and Azevedo, C. A. V. 2006. A new version of the Assistat-statistical assistance software. Pages 393-396 in: Abstr. World Cong. Comput. Agric. 4. Orlando, FL.

41. Slatkin, M. 1995. A measure of population subdivision based on microsatellite allele frequencies. Genetics 139:457-462.

42. Sommerhalder, R. J., McDonald, B. A., and Zhan, J. 2006. The frequencies and spatial distribution of mating types in Stagonospora nodorum are consistent with recurring sexual reproduction. Phytopathology 96:234-239.

43. Stoddart, J. A., and Taylor, J. F. 1988. Genotypic diversity: Estimation and prediction in samples. Genetics 118:705-711.

44. Tredway, L. P., Stevenson, K., and Burpee, L. L. 2003. Mating type distribution and fertility status in Magnaporthe grisea populations from turfgrasses in Georgia. Plant Dis. 87:435-441.

45. Tuite, J. F. 1969. Plant Pathological Methods, Fungi and Bacteria. Burgess Publishing Company, Minneapolis, MN.

46. Urashima, A. S., Bruno, A. C., and Lavorenti, N. A. 2001. Análise da segregação de avirulência de Magnaporthe grisea do trigo. Fitopatol. Bras. 26:644-618.

47. Urashima, A. S., Galbieri, R., and Stabili, A. 2005. DNA fingerprinting and sexual characterization revealed two distinct populations of Magnaporthe grisea in wheat blast from Brazil. Czech J. Genet. Plant Breed. 41:238-245.

48. Urashima, A. S., Grosso, C. R. F., Stabili, A., Freitas, E. G., Silva, C. P., Netto, D. C. S., Franco, I., and Bottan, J. H. M. 2009. Effect of Magnaporthe grisea on seed germination, yield and quality of wheat. In: Advances in Genetics, Genomics and Control of Rice Blast Disease. G.L. Wang and B. Valent, eds. Springer Netherlands, Dordrecht, The Netherlands.

49. Urashima, A. S., Hashimoto, Y., Don, L. D., Kusaba, M., Tosa, Y., Nakayashiki, H., and Mayama, S. 1999. Molecular analysis of the wheat blast population in Brazil with a homolog of retrotransposon MGR583. Ann. Phytopathol. Soc. Jpn. 65:429-436.

50. Urashima, A. S., Igarashi, S., and Kato, H. 1993. Host range, mating type, and fertility of Pyricularia grisea from wheat in Brazil. Plant Dis. 77:1211-1216.

51. Urashima, A. S., Leite, S. F., and Galbieri, R. 2007. Eficiência da disseminação aérea em Pyricularia grisea. Summa Phytopathol. 33:275279.

52. Valent, B., and Chumley, F. G. 1991. Molecular genetic analysis of the rice blast fungus, Magnaporthe grisea. Annu. Rev. Phytopathol. 29:443467.

53. Xu, J. R., and Hamer, J. E. 1995. Assessment of Magnaporthe grisea mating type by spore PCR. Fungal Genet. Newsl. 42:80.

54. Zadoks, J. C., Chang, T. T., and Konzak, C. F. 1974. A decimal code for the growth stages of cereals. Weed Res. 14:415-421.

55. Zhan, J., Kema, G. H., Waalwijk, C., and McDonald, B. A. 2002. Distribution of mating type alleles in the wheat pathogen Mycosphaerella graminicola over spatial scales from lesions to continents. Fungal Genet. Biol. 36:128-136.

56. Zhan, J., Pettway, R. E., and McDonald, B. A. 2003. The global genetic structure of the wheat pathogen Mycosphaerella graminicola is characterized by high nuclear diversity, low mitochondrial diversity, regular recombination, and gene flow. Fungal Genet. Biol. 38:286-297. 